\title{
DESENCONTRO: AMOR E FEMININO EM BENJAMIM, DE CHICO BUARQUE
}

RESUMO:

Este trabalho analisa o segundo romance de Chico Buarque, Benjamim, examinando as articulações entre os discursos feminino e amoroso, com abordagem psicanalítica e semiológica. Promove ainda um diálogo com o primeiro romance do autor, Estorvo, em que já se encontram traços da feminização a que é submetido o sujeito amoroso.

PALAVRAS-CHAVE: Chico Buarque, romance, Benjamim, amor, feminino.

\begin{abstract}
Brincadeira de criança: havia um certo número de crianças e de cadeiras, menos uma; enquanto as crianças dançavam em volta, uma senhora tocava piano; quando ela parava, cada um se precipitava sobre uma cadeira e se sentava, menos o mais tolo, o menos brutal, ou o mais azarado, que continuava de pé, bobo, sobrando: o enamorado...
\end{abstract}

Roland Barthes

Desde a década de 60, Chico Buarque é um nome conhecido no cenário musical. Porém, apesar de mais famoso, o cantor e compositor parece ter sido antecedido pelo escritor, já que a literatura foi tendo várias manifestações paralelas e, muitas vezes, anteriores a sua produção musical. Seu percurso literário inclui vários gêneros: contos, crônicas, novela, poesia, literatura infantil, textos teatrais, artigos para jornal e, finalmente, romances.

A estréia na ficção aconteceu em 1974, com a novela Fazenda Modelo. Em 1981, foi publicado o poema A bordo do Rui Barbosa, escrito por volta de 1963, e com desenhos de Vallandro Keating. Outra aproximação com a literatura ocorreu com as peças teatrais: Roda viva, em 1968; Calabar, o elogio da traição, em 1973, em parceria com Ruy Guerra; Gota d'água, com Paulo Pontes, em 1975, e Ópera do * Mestre em Letras: Estudos Literários (Área de concentração: Literatura Brasileira), 2001. 


\section{EMTESE}

Belo Horizonte, v. 6, p. I-253, ago. 2003

malandro, em 1978. Ainda para o teatro, escreveu, desta vez para crianças, 0 corsário do rei, com Edu Lobo, adaptou e traduziu para o português Os saltimbancos, montada em 1977. Em 1979, lançou o livro infantil Chapeuzinho Amarelo. Além da criação musical e literária, mais uma faceta de sua capacidade criativa seria revelada com a invenção, em 1974, dos pseudônimos Leonel Paiva e Julinho de Adelaide, este, na verdade, quase um heterônimo.

Estorvo, o primeiro romance, de 1991, foi publicado em diversos países e ganhou, em 1992, o prêmio Jabuti de Literatura de melhor livro de ficção. Apesar do sucesso e da aprovação de vários intelectuais, como Leyla Perrone-Moisés, Roberto Schwarz, Augusto Massi, Alfredo Bosi, Benedito Nunes, José Cardoso Pires, Estorvo provocou estranhamento no leitor e reprovação de parte da crítica, já que, para alguns, tratava-se de uma exceção, pois era um romance escrito por um compositor. Quando foi lançado Benjamim, em 1995, parecia ser relevante ainda o fato de o autor ser um artista da MPB que migrou para a literatura.

Os romances possuem vários elementos em comum: seqüência não-linear; recorrência de flashbacks, atmosfera ambígua entre realidade e sonho, repetições de cenas, nomes incomuns ou ausência deles, clima onírico, tom vertiginoso, a presença constante de um olhar perturbador e persecutório, fixação por bocas de mulheres, em Benjamim, e por pés, em Estorvo, personagens obcecadas. 0 protagonista de Estorvo, "ovelha negra" da família de classe média alta, e Benjamim, desdenhado e repelido pelas mulheres, são "estorvos", sujeitos sem rumo e sem afeto, emaranhados no turbilhão dessas narrativas circulares.

Apesar de Estorvo e Benjamim possuírem um enredo policial, que, por sua própria natureza, privilegia um sentido, há, nas narrativas, momentos de uma dicção da escrita feminina ${ }^{1}$, quando, por exemplo, fala-se do movimento característico do corpo feminino, sempre único para cada mulher, das bocas voluptuosas, ou quando se fala do amor.

Em Estorvo, o corpo feminino aparece com insistência, beirando uma escrita que privilegia a inserção do corpo no discurso e sua presença/ausência, corpo que é puro movimento por baixo da roupa - ao mesmo tempo em que está lá, só se vislumbra sua ausência, seu mais além, lugar de puro vazio, que é o feminino. 
Nesses textos, as mulheres têm destaque: mesmo sem fala, elas rodeiam os protagonistas e influenciam de alguma forma suas vidas. Em Estorvo, são a mãe ausente, a irmã rica que the dá dinheiro, a ex-mulher que o sustentava. Em Benjamim, são duas mulheres cujas lembranças ou aparições atormentam o personagem principal, levando-o à decadência.

Toda a narrativa de Benjamim se estrutura em torno de um desejo - a perseguição do personagem à antiga namorada e a repetição desse gesto com Ariela, na tentativa de ser reconhecido. A narrativa também se constrói sobre uma perda: 0 para sempre perdido objeto de desejo do protagonista.

Benjamim é um ex-modelo fotográfico decadente que fez sucesso na juventude, inclusive entre as mulheres, mas por quem hoje "ninguém dá nada" (89) 0 título é uma ironia, já que Benjamim, que significa o filho preferido, perdeu esse estatuto e, atualmente, não é preferido de ninguém. 0 que ele parece buscar, longa e incansavelmente, nessas figuras femininas, é aquela que, ilusoriamente, seria capaz de the suturar a falta, de preencher o vazio a que parece fadado. Mas elas se recusam a esse papel, e fogem.

Ariela Masé inicia um movimento em sua direção, mas recua. Ela é objeto de desejo de vários homens, porém não se deixa capturar por nenhum e nem se mostra completamente a eles. Todos os personagens masculinos que a rodeiam parecem ser, de alguma forma, sujeitos falhados, heróis decaídos que beiram o patético. Já Castana Beatriz, primeira depositária do desejo de Benjamim, mesmo morta, é soberana em seus pensamentos.

Na tentativa de manter viva a amada do passado, Benjamim a substitui por Ariela, moça que supostamente (nos delírios de Benjamim?) seria filha de Castana. Ele identifica as duas mulheres em tal nível que busca fazer de uma representação da outra: os mesmos cachos, a boca, e o suposto grau de parentesco entre ambas. Mesmo que, em determinados momentos, Benjamim pareça ter consciência disso, em outros, o amor supera esse saber e Castana volta a ser fantasiada na figura de Ariela. Tal fantasia é que o move e o leva a reatualizar o constante fracasso do seu desejo irrealizado, se deparando sempre com a falta e com o desencontro.

A Pedra cumpre aî papel especial, com sua sombra e seu cheiro, que estão por toda a casa e no próprio Benjamim. Essa pedra com $\mathrm{P}$ maiúsculo possui presença 


\section{EMTESE}

Belo Horizonte, v. 6, p. I-253, ago. 2003

tão forte que se personifica, servindo de túmulo para o objeto perdido do personagem, ao sedimentar seu eterno luto e ajudar a manter a presença da morta dentro dele. Com isso, Benjamim rejeita a realidade e cria uma nova, alucinada.

A presença interna da amada gera em Benjamim, no decorrer de sua vida, o impulso à repetição: perseguindo Castana e, anos mais tarde, repetindo esse gesto com Ariela. Desaparece uma mulher, reaparece outra, e assim sucessivamente, como no "fort-da" da brincadeira infantil analisada por Freud. Nessa análise, Freud fala da compulsão à repetição da experiência aflitiva, que sobrepuja o princípio de prazer. ${ }^{3}$ Benjamim repete, de forma ativa, a busca por uma mulher, mas também repete passivamente outras experiências resultantes dessa busca - é levado aos mesmos lugares em que procurava Castana e morre na mesma casa onde ela morou e morreu.

Como se vê, o feminino percorre todo o segundo romance de Chico Buarque, seja através do homem que se feminiza em busca de seu objeto de desejo, seja através das mulheres, que colocam o protagonista diante de sua falta original.

0 feminino é percebido também nos corpos que se revestem de signos que mascaram e cobrem a falta. Disso parece saber Benjamim, ao falar das mulheres quando destituídas desses ornamentos fálicos: ele notou "que mulheres também mínguam à medida que tiram a roupa, os brincos, a pintura, do mesmo modo que uma sala míngua quando é despojada da mobília" (42). A fenda, elemento recorrente em Benjamim, falanos dessa falta, através do vácuo e dos volteios das bocas pintadas, enormes, onde o sujeito se abisma. A lacuna, o vão, o abismo dentro das bocas remetem à fenda e à fissura que a questão feminina engendra: vazio primordial da castração e que não obtura a falta. Tais bocas nada mais exibem que os signos que cobrem a vacuidade, a impossibilidade, marcas de Benjamim e de Estorvo.

0 vazio e a impossibilidade, marcas do feminino, refletem-se também em outro discurso presente em Benjamim: o amoroso. A impossibilidade ocorre porque "não há relação sexual"; o que existe é o desencontro entre os seres falantes; a fusão tão desejada pelos amantes, a união perfeita, tal como no mito do Andrógino, não se concretiza.

A íntima ligação entre afeto e feminino é assinalada em $A$ traição de Penélope, quando a autora define a escrita feminina como a "escrita dos afetos" - 
dos amores, das dores, das melancolias, dos ressentimentos, das perdas ${ }^{3}$. A privação, porém, "questão primordialmente feminina"4, segundo Adélia Bezerra de Meneses, é sofrida, nos romances de Chico Buarque, pelos homens. 0 homem que sofre da falta e persegue loucamente suas mulheres é o mesmo apaixonado que espera e, que, portanto, segundo Roland Barthes, torna-se feminizado.

Barthes afirma que o homem torna-se feminizado quando fala a ausência do outro, ou seja, quando se apaixona. Benjamim feminiza-se na medida em que sua existência de sujeito apaixonado resume-se na perseguição e na espera, inútil e desesperada, das duas amadas. Tal espera aponta para a incompletude, pois não há reciprocidade nem fusão amorosa. Diante da impossibilidade da relação sexual, falta que leva a uma fala incessante, Benjamim pagaria a Lorna para dizer "tu és meu bem, tu és meu bem, tu és meu bem" (134), num discurso esvaziado de sentido, assim como a ex-mulher do protagonista de Estorvo carrega seu discurso amoroso de um excesso de palavras que nada dizem, quando fala eu te amo "no meio do almoço, no cinema, no supermercado, na frente dos outros" ( 37 ). 0 "eu-te-amo" sufoca o sujeito, que acaba se acostumando com as palavras, já que a elas não pode responder.

Da impossibilidade de sustentação desse discurso, já que é uma tentativa inútil de preencher de sentidos o que nada significa, surge a errância: Benjamim é destinado a errar, de mulher em mulher, até a morte, numa repetição compulsiva do mesmo gesto. Compulsão que é resultado da tentativa impossível, mas sempre almejada pelos amantes, de fazer, de dois, o Um, na busca pela complementaridade, que tem eco no mito do Andrógino atrás de sua outra metade. Benjamim, tal qual o Andrógino, cindido, lança-se a essa busca vã, mas como observa Lacan, tal unidade não existe, já que "não há relação sexual", no sentido matemático de proporção, restando apenas uma hiância, um vazio, o desencontro entre os seres falantes.

Benjamim, atrás dessas mulheres, apenas concretiza a impossibilidade de fusão, mas disso não tem consciência e disso não quer saber, insistindo na crença de soma dos apaixonados e da possibilidade de realização plena do amor, preferindo continuar sua busca obstinada que o leva ao apagamento e à morte. Vivendo dessa crença, ele não ouve o "não" de Ariela: palavra nunca proferida, mas dita o tempo todo, com o silêncio, o afastamento, a fuga. Benjamim também não profere o discurso amoroso, e, na única tentativa de fazê-1o, o gesto torna-se patético: 


\section{EM TESE}

Belo Horizonte, v. 6, p. I-253, ago. 2003

0 táxi entra num túnel mal iluminado, e Benjamim envolve a mão de Ariela, que continua cerrada, óssea. Na dianteira, um caminhão de lixo larga lufadas de fumaça, que Benjamim não se incomoda de aspirar fundo para declarar: "Este é um dos melhores acontecimentos da minha vida". Metade da frase cai fora do túnel, em tom alto, e deve soar estapafúrdia à luz do dia porque Ariela recolhe a mão, e o motorista dá uma gargalhada rouca. (163)

Benjamim anda em círculos até seu trágico destino e só the é possível a saída da morte, tal qual no mito edipiano. Sem a fantasia que o apoiava, representada por Castana e Ariela, ele vaga sem rumo, dá voltas em redor do nada, do vazio. Sem direção, o sujeito entra em decadência, pois o mesmo Benjamim que antes andava "rindo à toa" (101), fica perdido se a mulher não aparece: "quem entreabre a porta é um senhor curvo, a camisa para fora da calça surrada, os cabelos brancos em desordem e a barba por fazer há uns sete dias" (161).

Vazio e impossibilidade: marcas do feminino, marcas do amor. Benjamim. Sujeito apaixonado. Feminizado. Sozinho. Como na brincadeira infantil, em que as crianças dão voltas ao redor da cadeira, ele dá voltas ao redor das mulheres, repetindo compulsivamente e deixando-se ser levado por uma voragem que é a fantasia necessária à sua existência, e, por fim, só, sobrando, soçobrando, à deriva, como um barco perdido em alto-mar:

Errar pelas tuas sendas, perseguir-te em vão, dissipar-me nisso. Que me importa o desgaste? A espera que me mobiliza é puro nomadismo - incontáveis as vezes em que pude partir imaginariamente, ser 0 itinerante, dizer-me adeus para te encontrar. Vivo da repetição onde me perco, devaneio que me leva, voragem. Quero o excesso... (Millan, 1999: 52)

NOTAS:

1. Refiro-me aqui ao conceito de "escrita feminina", desenvolvido por Lúcia Castello Branco nos livros $O$ que é escrita feminina e $A$ traição de Penélope.

2. Baseio-me em análise feita por Ruth Silviano Brandão em Mulher ao pé da letra, p. 97. Cf. Freud, 1998: 18-21.

3. 0 afeto é aqui entendido como "aquilo que afeta". Essa língua do feminino fala em uma linguagem outra - linguagem do sentido-sensação, sentido-sentimento e sentido múltiplo, multidirecional, linguagem dos rumores, dos gemidos e dos silêncios e também da tagarelice. (Cf. Castello Branco, 1994: 68-69.)

4. A autora analisa a canção "Pedaço de mim", que "se desenvolve como um diálogo de um homem e de uma mulher num momento de despedida" e na qual, segundo ela, "mesmo a fala atribuída à personagem masculina revela uma posição feminina", um sentimento feminino de perda, falta, privação. (Cf. Meneses, 2000: 147.) 
ABSTRACT :

This work analyses Benjamim, by Brazilian writer and composer Chico Buarque, and examines the articulations between feminine discourse and love discourse from a semiological and psychoanalytical viewpoint. It also intends to promote a dialogue with his first novel, Estorvo, where one already verifies traces of the feminization the love subject undergoes.

KEY WORDS: Chico Buarque, novel, Benjamim, love, feminine.

\section{REFERÊNCIAS BIBLIOGRÁFICAS}

BARTHES, Roland. Fragmentos de um discurso amoroso. Trad. Hortênsia dos Santos. 14. ed. Rio de Janeiro: Francisco Alves, 1998.

- O prazer do texto. Trad. J. Guinsburg. 4. ed. São Paulo: Perspectiva, 1996.

BRANDÃo, Ruth Silviano. Literatura e Psicanálise. Porto Alegre: Editora da Universidade Federal do Rio Grande do Sul, 1996.

- Mulher ao pé da letra; a personagem feminina na Literatura. Belo Horizonte: Editora UFMG/Secretaria Municipal de Cultura de Belo Horizonte, 1993.

BUARque, Chico. Benjamim. São Paulo: Companhia das Letras, 1995.

- Estorvo. 1. reimp. São Paulo: Companhia das Letras, 1991.

CASTELLO BRANCO, Lúcia. o que é escrita feminina. São Paulo: Brasiliense, 1991. 1994. - A traição de Penélope. São Paulo: Annablume, 


\section{EM TESE}

Belo Horizonte, v. 6, p. I-253, ago. 2003

FREUD, Sigmund. Além do princípio de prazer. Trad. Christiano Monteiro Oiticica. Rio de Janeiro: Imago, 1998.

LACAN, Jacques. O seminário; livro 20: mais, ainda. Trad. M. D. Magno. 2. ed. Rio de Janeiro: Jorge Zahar Editor, 1985. p.87-104: Deus e o gozo d'A Mulher.

MENESES, Adélia Bezerra de. Figuras do feminino na canção de Chico Buarque. Cotia: Ateliê Editorial, São Paulo: Boitempo Editorial, 2000.

MILAN, Betty. E o que é o amor? Rio de Janeiro: Record, 1999.

NASI0, Juan-David. O livro da dor e do amor. Trad. Lucy Magalhães. Rio de Janeiro: Jorge Zahar Editor, 1997.

POMMIER, Gérard. A exceção feminina; os impasses do gozo. Trad. Dulce M. P. Duque Estrada. Rio de Janeiro: Jorge Zahar, 1997.

SOARES, Luiz Felipe Guimarães. Estorvo e outros estorvos. Florianópolis: Faculdade de Letras da UFSC, 1996. (Dissertação, Mestrado em Literatura Brasileira).

WERNECK, Humberto. Chico Buarque; letra e música. 2. ed. 3. reimp. São Paulo: Companhia das Letras, 1997. v.1. 